James D. Fry, Bryane Michael and Natasha Pushkarna

\title{
The values of
}

international

organizations

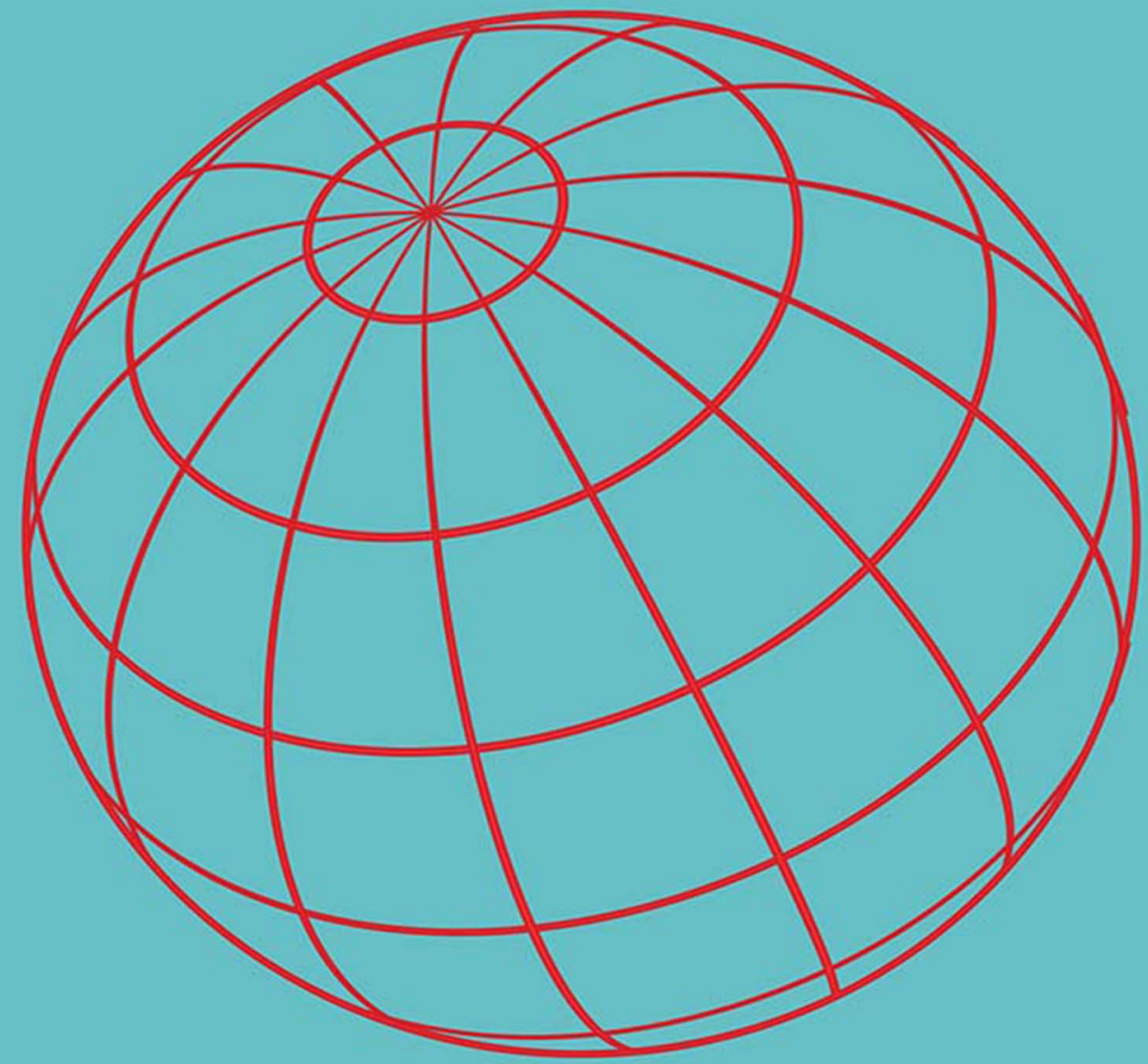

James D. Fry, Bryane Michael, and Natasha Pushkarna - 9781526152428 
The values of international organizations

\section{MANCHESTER 1824}

Manchester University Press 
Melland Schill Studies in International Law

General editors Iain Scobbie and Jean D'Aspremont

MELLAND SCHILL

Founded as a memorial to Edward Melland Schill, a promising scholar killed during the First World War, the Melland Schill Lectures (1961-74) were established by the University of Manchester following a bequest by Edward's sister, Olive B. Schill, to promote the understanding of international law and implicitly lessen the possibilities for future conflict. Dedicated to promoting women's employment rights and access to education, Olive's work is commemorated in both the Melland Schill series and the Women in International Law Network at the University of Manchester.

The Melland Schill lecture series featured a distinguished series of speakers on a range of controversial topics, including Quincy Wright on the role of international law in the elimination of war, Robert Jennings on the acquisition of territory, and Sir Ian Sinclair on the Vienna Convention on the Law of Treaties.

In the 1970s, Gillian White, the first woman appointed as a Professor of Law in mainland Britain, transformed the lectures into a monograph series, published by Manchester University Press. Many of the works previously published under the name 'Melland Schill monographs' have become standard references in the field, including: A.P.V. Rogers' Law on the battlefield, which is currently in its third edition, and Hilary Charlesworth and Christine Chinkin's The boundaries of international law, which offered the first book-length treatment of the application of feminist theories to international law.

Closely linked to the Melland Schill Studies in International Law series and carefully supervised by the editors, these volumes have been updated and reissued in paperback with new material.

Principles of direct and superior responsibility in international humanitarian law Ilias Bantekas

The treatment and taxation of foreign investment under international law Fiona Beveridge

War crimes and crimes against humanity in the Rome Statute of the International Criminal Court Christine Byron

The boundaries of international law Hilary Charlesworth and Christine Chinkin

The law of the sea Robin Churchill and Vaughan Lowe

International law and policy of sustainable development Duncan French

The changing rules on the use of force on international law Tarcisio Gazzini
Contemporary law of armed conflict Leslie Green

Child soldiers in international law Matthew Happold

Human rights in Europe J.G. Merrills and A.H. Robertson

The rights and duties of neutrals Stephen Neff Law on the battlefield A.P.V. Rogers

Indigenous peoples and human rights Patrick Thornberry

Jurisprudence of international law Nicholas Tsagourias

The law of international organisations Nigel D White 


\title{
The values of \\ international organizations
}

\author{
James D. Fry, Bryane Michael \\ and Natasha Pushkarna
}


Copyright (C) James D. Fry, Bryane Michael and Natasha Pushkarna 2021

The right of James D. Fry, Bryane Michael and Natasha Pushkarna to be identified as the authors of this work has been asserted by them in accordance with the Copyright, Designs and Patents Act 1988.

Published by Manchester University Press

Altrincham Street, Manchester M1 7JA

www.manchesteruniversitypress.co.uk

British Library Cataloguing-in-Publication Data A catalogue record for this book is available from the British Library

ISBN 9781526152411 hardback

First published 2021

The publisher has no responsibility for the persistence or accuracy of URLs for any external or third-party internet websites referred to in this book, and does not guarantee that any content on such websites is, or will remain, accurate or appropriate.

Typeset by

Servis Filmsetting Ltd, Stockport, Cheshire 